Gerd Johansen is associate professor at the Norwegian University of Life Sciences. Her research interests are scientific literacy, education for sustainable development, science teacher education and science for students in vocational programs.

Miranda Rocksén is senior lecturer at the Department of pedagogical, curricular and professional studies at the University of Gothenburg. Her research interest encompasses to study science teaching and learning processes through the details and patterns that develop in the communication between teachers and students.

Birgitte Bjønness is associate professor at the Norwegian University of Life Sciences. Her research interest are education for sustainable development, biology education, and inquiry-based teaching and learning.

\title{
GERD JOHANSEN
}

Norwegian University of Life Sciences, Norway

gerd.johansen@nmbu.no

\section{MIRANDA ROCKSÉN}

University of Gothenburg, Sweden

miranda.rocksen@gu.se

\section{BIRGITTE BJФNNESS}

Norwegian University of Life Sciences, Norway

birgitte.bjonness@nmbu.no

\section{The use of examples in school science: Developing an analytical tool to enable a discussion in science teacher education}

\footnotetext{
Abstract

Examples play important roles in science teaching as vehicles for both conceptual learning and affective engagement. In this article, we develop an analytical tool that deconstructs and deliberates on the use of examples in school science. This analytical tool approaches examples as part of social interactions in the classroom. The tool can be used to deconstruct the use of examples by identifying the relations among the actors, the types of knowledge and how knowledge is communicated. The tool then facilitates a deliberation on examples' epistemic affordance - their potential for pupils' learning. We apply the analytical tool on empirical materials from two classrooms where teachers and pupils (aged 15-16) work with examples connected to evolution, genes and traits. We presume that if this analytical tool is applied on authentic classroom materials in pre-service training, student teachers will benefit when they design or re-use examples in their own future teaching practices.
} 


\section{INTRODUCTION}

In this article, we propose an analytical tool that offers the possibility to inspect the use of examples and to deliberate on what the examples might afford for pupils' learning in school science. Despite the difficulty in making claims about what pupils learn from examples, the tool facilitates a deliberation on potential learning, the examples' epistemic affordance.

In science teaching and learning, examples coexist with other communicative devices, such as analogies and metaphors, and it is not always easy to distinguish among them. Additionally, when used in science education, the word examples might refer to different devices or objects, (e.g., textbook examples). Here, we approach examples as constituting a type of recurrent social action - as a classroom genre, where some science content is illustrated or made more concrete as part of the social interaction in the classroom.

Our intention is to support discussions about the use of examples as part of teacher education because decisions on how to teach science seem highly sensitive to beliefs about "what works" and teaching traditions (Bjønness \& Knain, 2018; Duschl \& Wright, 1989). Thus, our point of departure is that the use of examples seems to be a somewhat tacit part of teachers' knowledge.

Making the tacit explicit, building the knowledge of science teaching and learning practices in ways that are accessible and useable by teacher educators and their student teachers is fundamental to a pedagogy of teacher education and is a meaningful response to the calls for science teacher education reform (Berry \& Loughran, 2012, p. 413).

Following Berry and Loughran's (2012) argument, the analytical tool we propose might contribute to making the use of examples more explicit for student teachers. An analytical approach (e.g., an analytical tool) applied on authentic video materials from classrooms is one way to facilitate discussions with student teachers about the particular challenges involved in science teaching and learning (Martin \& Siry, 2012). Tools have a bidirectional effect (Cole \& Engeström, 1993); they simultaneously support the student teachers' understanding of how examples are used and their possible contribution to pupils' learning, as well as help the student teachers to be more aware when using examples themselves.

We apply this analytical tool on examples used in authentic science classrooms in Norway and Sweden, specifically involving 15-16-year-old pupils. In the Discussion section, we visualise the tool and explain its strengths and weaknesses and how it might support science teacher education. However, in the next three sections of this article, we first present a literature review on examples in science education, the concept of epistemic affordance and a theoretical exposition of the analytical tool.

\section{Examples in science education}

The science education literature has shown interest in communicative devices, such as analogies and metaphors, but the use of examples has not yet been equally thoroughly researched. There are no explicit references to the use of examples in The second international handbook of science education (Fraser, Tobin, \& McRobbie, 2011), the Handbook of research on science education (Lederman \& Abell, 2014) and the Encyclopedia of science education (Gunstone, 2015). However, the encyclopedia has several entries on analogies. Analogies serve many of the same purposes of teaching as those of examples, including to make pupils more familiar with science content and to build on what they already know (Coll, 2015). It is reasonable to assume that the use of examples shares many traits with the use of analogies.

We do need to make sure the analogy is interesting and familiar, and both the shared and unshared attributes need to be discussed. We must also point out where the analogy breaks 
down, lest students think the analogy and the target have things in common that they do not (Coll, 2015, p. 42).

Thus, if the analogy is not fully explained, it poses the risk that students might make connections other than those intended. Indeed, analogies used to support learning - because they are assumed to be recognisable - can cause an illusion of comprehension among students (Jaeger \& Wiley, 2015). The teacher thus needs to carefully plan teaching with analogies (Treagust, 2015). However, Marcelos and Nagem (2012) found that teachers did not use appropriate methodologies of teaching analogies. Due to the scarce literature on the use of examples in science teaching, it is necessary to investigate how examples are used and their potential for pupils' learning.

In a small-scale comparative study, Brown (1992) examined if examples could remediate misconceptions in physics and found that a carefully designed example made it more likely for high school students to grasp the concept of Newton's third law. When interviewing the students, he found that it was necessary for the examples to make sense to the students, which could also be interpreted as a call for "better" and not "more" examples. One factor that can help make examples better is that analogous situations be made explicit. For instance, regarding Newton's third law, a book on the table and a hand on the spring are "the same". However, these principal similarities might not be easy for the students to grasp.

There are many common examples as part of a shared school science culture; they are recycled by generations of teachers and pupils and are thus important in shaping the science content. However, there is the danger that pupils read more into examples than they have grounds for by making generalisations based on too flimsy "evidence".

\section{Epistemic affordance}

To deliberate on the examples' potential for pupils' learning, we apply the concept of epistemic affordance. The concept of affordance alludes to what the environment offers or provides to the individual and depends on what the environment's qualities are in relation to the individual's capabilities (Gibson, 1977). Gibson's (1977) examples of affordance are physical objects (e.g., a chair) and what they afford in relation to humans. However, our interest lies in investigating the affordance of knowledge objects as part of an activity (i.e., the use of examples). We denote this as epistemic affordance, which is a concept used in the field of technology-enhanced learning. It takes account of the medium, as well as the knowledge content, to denote possibilities for learning. For instance, Mavrikis, Noss, Hoyles, and Geraniou (2012) explored algebraic thinking when pupils used a specific ICT tool - and the epistemic affordances that this generated. In our case, what the science content is (e.g., evolution of traits) and how it is communicated and worked with provide the epistemic affordance in relation to pupils.

Mavrikis and colleagues (2012) pointed out that epistemic affordance should be considered in the light of its context. When using examples in the classroom, the vital elements of the context are the purpose and the goal of the activity. When using examples as part of school science, the teacher's goal is to engage the pupils - both cognitively and affectively. However, the balance between cognitive and affective engagement might vary. When using some examples, it would be feasible to include purposes and goals to foster ethical and aesthetic engagement.

Examples are supposed to help pupils understand abstract conceptual knowledge. One of the cognitive problems related to the use of examples might be its simplification of complex relations or concepts in science. There is thus the danger that the pupils read more into examples than they have grounds for (cf. Jaeger \& Wiley, 2015) by making generalisations based on one example. The affective aspects of examples are important in engaging pupils at an emotional level, which in turn can be 
perceived as the environment for conceptual learning - as well as valuable in itself (Alsop \& Watts, 2003). For instance, the choice between an exotic and a commonplace example might be crucial. The commonplace or the everyday type might trigger the pupils' lived experiences. On the other hand, the exotic example might give rise to other emotions. The media or the resources used are essential in generating both cognitive and affective engagement (e.g., through the choice of words or pictures). However, a direct connection between what the example affords and the learning outcome cannot be expected because "what people learn is a consequence of their actual activity, and therefore only indirectly a result of the task set for them. Tasks are designable, activities are not - they are emergent" (Goodyear, Carvalho, \& Dohn, 2014, p. 3).

\section{DeVEloping AN ANALYTiCAL TOOL tO INVESTigATE EXAMPLES}

We approach examples as one of the classroom genres (Martin \& Rose, 2008). Teachers and pupils participate in the unfolding of classroom genres in the course of teaching and learning, and these genres are so "naturalised" that they are almost never felt as constraints (Martin, 2009). Genres might be used to design teaching and learning sequences, where the design comprises three phases: deconstruction, the teacher's and the learners' joint construction and lastly, the learners' independent construction (Martin, 2009). In this article, we are mainly concerned about the deconstruction phase, yet it is perceived as crucial before student teachers can construct their own examples (cf. Martin, 2009).

When a teacher uses an example, it is easily recognised as such as long as the pupils are familiar with this aspect of the school culture. Martin (2009, p. 13) stated, "As far as its place in a functional model of language and social context is concerned, genre can be defined as a recurrent configuration of meanings and a culture as a system of genres", where the configuration of meaning can rely on speech, writing or gestures, among others. In this model of language and social context, an example follows certain patterns.

Genres are social, goal oriented and staged (Martin, 2009). Genres are undertaken in interaction - in the classroom, the teacher and the pupils jointly contribute to making and recognising the example. The examples are claimed to be goal oriented because they are intended to achieve something particular. For instance, the goal could be to promote pupils' conceptual, affective, aesthetic and/ or ethical notions. Examples are staged, and according to Martin and Rose (2008), consist of three chronological stages: orientation, incident and ends with an interpretation. Table 1 shows the stages of the genre examples. The orientation sets the scene, placing the example within a frame for how to understand it. The middle stage is the incident, which is a presentation and an explication providing details of the real-world phenomenon or process. The example ends with an interpretation, involving a judgement because it has to state what is true or good (Martin \& Rose, 2008).

Table 1. The stages of the genre example (adapted from Martin \& Rose, 20o8, p. 63)

\begin{tabular}{|l|l|}
\hline Stages & Explication for school science \\
\hline Orientation & A theory or a concept that sets the scene for what the example is about \\
\hline Incident & Presentation and explication of a concrete real-world phenomenon or process \\
\hline Interpretation & Judgement - expectation of correct explanation \\
\hline
\end{tabular}

The orientation points to the incident; so does the interpretation. This means that the incident or the concrete real-world phenomenon or process is chosen because of the orientation and that the interpretation follows as "a consequence" of the incident. In other words, no direct link exists between the initial orientation and the final interpretation. 


\section{Deconstructing examples}

Genres are recurrent configurations of meanings, where the meanings that unfold in social situations can be described by the register variables: tenor, field and mode (Martin \& Rose, 2008). However, to facilitate the use of the tool, we couple the register variables more directly with communication in science classrooms.

- Who are involved, and what are their social relations? (The tenor variable.) Martin and Rose (2008) provided two dimensions of tenor: status and solidarity. People with an equal status have access to and can make the same type of choices (e.g., rise and leave when they want). In the use of examples, the status can be observed in who is controlling the topic and its progress. Solidarity is concerned with social distance and deals with how the actors engage in interpersonal considerations and include one another. We would like to add that in a classroom, inclusion might be perceived differently by the teacher and the pupils.

- What knowledge is at stake? (The field variable.) Martin and Rose (2008) provided two dimensions: how the knowledge is structured and how general/specific it is. The structure of knowledge is related to activity, that is, if a) the knowledge is activity structured (e.g., processes - "it does") or b) non-activity structured (e.g., classifications - "it is"). For our more practical approach, "is" and "does" are translated into "conceptual knowledge" and "scientific knowledge processes", respectively. Scientific knowledge processes deal with how science is produced and validated (cf. the nature of science [Lederman \& Lederman, 2014]). The other dimension tackles general (e.g., evolution) or specific knowledge (e.g., a giraffe's long neck).

- How is knowledge communicated? (The mode variable.) According to Martin and Rose (2008), this involves a) whether the communication is dialogic or monologic and b) the dependence on verbal language. However, as communication in classrooms is seldom purely verbal, it is necessary to take into account how different forms of communication (e.g., writing and drawings on the blackboard) interact with speech, in other words, how components of the multimodal assembly work together.

Table 2. Overview of questions related to the register variables (who, what and how)

\begin{tabular}{|c|c|c|}
\hline $\begin{array}{l}\text { Tenor variable } \\
\text { Who ... }\end{array}$ & $\begin{array}{l}\text { Field variable } \\
\text { What ... }\end{array}$ & $\begin{array}{l}\text { Mode variable } \\
\text { How ... }\end{array}$ \\
\hline $\begin{array}{l}\text { - is in control? } \\
\text { - is included? }\end{array}$ & $\begin{array}{l}\text { - } \quad \text { keneral/specific conceptual } \\
\text { knowledge is conveyed? } \\
\text { general/specific processes } \\
\text { for construction of scientific } \\
\text { knowledge are conveyed? }\end{array}$ & $\begin{array}{l}\text { - is knowledge communicated? } \\
\circ \quad \text { dialogue versus monologue } \\
\circ \quad \text { multimodal assembly }\end{array}$ \\
\hline
\end{tabular}

In Table 2, we provide an overview of the questions that focus on the forthcoming deconstruction of the examples. In the development of the analytical tool, the register variables are combined with the stages (Table 1). Doing so makes it possible to describe in detail how the teacher and the pupils jointly communicate on science content when using examples.

\section{Deliberating on examples' epistemic affordance}

When the teacher chooses to use an example, the goal is that the pupils should learn something. However, as already pointed out in this article, learning from examples is not a straightforward process. To explore what an example might afford for pupils' learning, we deliberate on the example's epistemic affordance. The main inputs to the deliberation comprise the what and the how of the communication (i.e., the output of the deconstruction). We are mainly concerned with two aspects of the pupils' learning: science content (conceptual knowledge) and scientific knowledge processes. We pose two questions to focus on the deliberation: 
- What are an example's potentials for pupils' conceptual understanding?

- What opportunities concerning scientific knowledge processes does the example provide to pupils?

\section{DECONSTRUCTING AND DELIBERATING ON EXAMPLES}

In this section, we apply the analytical tool to deconstruct two different examples - the giraffe and genes' control traits - and to deliberate on their epistemic affordance for pupils. In both cases, the teachers are experienced and have good relationships with their pupils. All excerpts from the classroom communication are translated by the authors. First, a short introduction to the knowledge at stake in these examples is presented.

\section{Teaching and learning about evolution and inheritance of traits}

Evolution and genetics are core topics in biology education, providing pupils with crucial knowledge to understand nature and society. However, the topics are regarded as difficult to teach and learn (e.g., Smith, 2010; Williams, Montgomery, \& Manokore, 2012). The current understanding of evolution includes both natural selection, as proposed by Darwin, and modern genetics. At the core is a series of concepts and claims about those concepts (see Smith, 2010, p. 241). An example is the concept of variation, which is caused either by genetic differences or by the effect of environmental factors on the expression of genetic potentials. The concepts of DNA and inheritance are crucial to understand the variations among individuals in a population and are thus fundaments for evolution. The inheritance of traits typically involves genetics, which entails unseen processes at different organisational levels (e.g., proteins, genes, chromosomes, cells, organs) and is characterised as abstract and difficult to learn (Williams et al., 2012). Teleological explanations (the position that things are made for a reason), as well as simplified causal explanations, are emphasised as obstacles to learning both evolution and genetics, where explanations are often complex and dependent on many co-occurring conditions. Concepts, such as adaptation, inheritance and evolution, are understood through different time scales involving several biological organisational levels and the influence of chance (e.g., Emmons \& Kelemen, 2015; Smith, 2010; Trommler, Gresch, \& Hammann, 2018). One task for science teachers is to address the difficulties, for example, the misunderstanding of evolution as a direct process, as well as facilitate pupils' understanding of evolution as an emergent process (Chi, 2005; Smith, 2010).

A giraffe's long neck is commonly used in school science to illustrate evolution. It is a classical problem, first known in Lamarck's (1914/1984) writings, where he claimed that the long neck appeared to be the result of giraffes' efforts to reach the leaves of trees in places with otherwise arid and barren soils. This description of evolution as a more or less direct process driven by the habit of giraffes was opposed by Darwin. In more recent evolutionary theories, the long neck is perceived as a reproductive advantage in the complex and emergent process of natural selection, which involves many factors and effects. In Williams' (2016) explanation, combinations of factors, such as high browse, sexual selection, function in thermoregulation, effects of climate change and horizon vigilance, have influenced the development of the long neck.

To illustrate human traits of simple inheritance, examples such as rolling the tongue and folding the hands are commonly used in biology education, in this case, illustrated by rolling the tongue. The example conveys the understanding that the trait of rolling the tongue is controlled by a single dominant gene. However, research (some conducted over 60 years ago, e.g., Matlock, 1952) shows that people can learn to roll their tongues, suggesting environmental factors (not solely genes) influencing the trait. Despite the knowledge of the complexity of human traits and inheritance, the myth continues to be taught and illustrated in science classrooms and textbooks. 


\section{First example: The giraffe}

The video data used in this section is part of a previous research project (Rocksén, 2015). The selected episode is taken from the start of the biological evolution topic in a Swedish ninth-grade class (15-year-old pupils). The teacher introduced the evolution of traits by using the giraffe example. Four simultaneous cameras were used for the recordings. Two cameras took close-up shots of two groups, one camera followed the teacher, and one camera took a panoramic shot of the classroom.

\section{The giraffe deconstructed}

At the start of the lesson, the teacher asks the pupils to make associations with the two words evolution and genetics during a brainstorm-like activity. The teacher writes down the pupils' contributions on the board. She is in control and includes the pupils by giving them a task. The brainstorm and the written notes on the board mark the example's orientation (see Table 3). In the incident, the teacher talks about giraffes' long necks and writes this question on the board: "Why do giraffes have such long necks?" The knowledge that the teacher asks for is specifically connected to giraffes, not to evolution in general. The question does not explicitly call for an explanation of scientific knowledge processes (i.e., "How do we know this?"). Next, she tells the pupils to work in small groups and to provide a written explanation about the question. The pupils later explain their answers to this question (i.e., the second part of the incident). The communication is monologic as the question is presented to the pupils rather than generated by or together with them.

Table 3. The giraffe example: orientation and incident

\begin{tabular}{|l|l|l|l|}
\hline Stage & Who & What knowledge & How \\
\hline Orientation & $\begin{array}{l}\text { Teacher controls } \\
\text { Pupils are invited to } \\
\text { participate (included) }\end{array}$ & $\begin{array}{l}\text { Biological evolution } \\
\text { and genetics - general } \\
\text { knowledge }\end{array}$ & $\begin{array}{l}\text { Oral brainstorm activity, } \\
\text { dialogic - relying on verbal } \\
\text { communication }\end{array}$ \\
\hline Incident & $\begin{array}{l}\text { Teacher controls } \\
\text { Pupils are included } \\
\text { less }\end{array}$ & $\begin{array}{l}\text { Giraffes have developed } \\
\text { long necks. Why? - } \\
\text { specific conceptual } \\
\text { knowledge }\end{array}$ & $\begin{array}{l}\text { Teacher's oral instruction and } \\
\text { question on the board } \\
\text { Monologic and relying on } \\
\text { verbal communication }\end{array}$ \\
\hline
\end{tabular}

In the second part of this incident, the pupils start to elaborate on the giraffes' long necks. At the end, they present their interpretation of the example in the form of a written text. We present how the incident and the interpretation unfold in one of the groups (see Table 4 for the summary).

In this group, Anna, Sofia and Jenny engage in a 15-minute discussion about how the giraffes' long necks developed. They use gestures, laugh and talk vividly - also to their classmates around them. In the course of this discussion, they develop their answer. Excerpt 1 shows a brief part of their discussion. 
Excerpt 1. The excerpt from a group discussion (slightly edited for readability; see the Appendix for the full version in Swedish)

\section{Time interval [0:31:54-0:32:45]}

Anna $\mathrm{Mm}$, so that it may reach the leaves, ehh, well, because, because so many... because so many as possible will survive, ehh, they develop to get long necks. Those who have long necks will get more food. They turn stronger; they live through fights and they live, and their children survive and then all become such nice giraffes. (laughter and a couple of short exchanges among the students)

(con- Anna Because the good food is up there, and then it is those giraffes that are tall that tinues) have access, and then they will become stronger, and then it...

Jenny Yes.

Anna And then they give birth to children, and then they win like this, or if it is like fights, so they are running from a lion, for example, then they win because they are so strong because they get so good food, and then when they get a calf, that will also become a nice one.

Their discussion is based on Anna's idea that leaves on top of trees are more nutritious than leaves on the lower branches, a knowledge claim that can be characterised as general. At one point, the discussion turns into some sort of story with a happy ending - the survival of long-necked giraffes, a specific knowledge claim. The pupils provide claims but do not try to validate or assess their claims. This part of the discussion is led by Anna although she includes the other group members in the dialogue. Moreover, their discussion is driven by verbal language, and they seem to have positive feelings for the giraffe (e.g., indicated by using words such as "good" and "nice one"). After 15 minutes of discussing and writing, they finish and hand in their text to the teacher; a part of it is provided in Excerpt 2.

Excerpt 2. Details from the text handed in by the group.

We think that this is because an animal such as the giraffe needs a lot of nutrients in the food. If there [are] more nutrients in the leaves of tall trees[,] then the body of the giraffe will develop so that it can reach the leaves. The giraffes that from the beginning were taller than the other giraffes got more access to the nutritious food. They became stronger and could [more easily] survive, and then they got calves that inherited the long neck. The giraffes with shorter necks did not survive, and could therefore not reproduce themselves.

The preceding text includes a rather straightforward causal explanation, noting that giraffes need nutritious food, the leaves on top of trees are more nutritious, and then the body of the giraffe develops so that it can reach these leaves. The text ends with a comment about unsuccessful reproduction among giraffes with shorter necks. Their knowledge claims are based on the assumptions that top leaves are more nutritious and that shorter giraffes do not reproduce. These claims indicate generality, so we argue that they are general yet specific because they relate to the giraffe species. The causal explanation is the answer to the teacher's question, and it gives two interlinked causes of the result (long neck). 
Table 4. The giraffe example: incident and interpretation of a group of pupils

\begin{tabular}{|l|l|l|l|}
\hline Stage & Who & What knowledge & How \\
\hline Incident & $\begin{array}{l}\text { Pupils include one } \\
\text { another; one of them } \\
\text { makes most of the } \\
\text { contributions }\end{array}$ & $\begin{array}{l}\text { Knowledge about the giraffe, its } \\
\text { anatomy, food and predators (spe-- } \\
\text { cific conceptual knowledge) } \\
\text { Making claims without validation }\end{array}$ & $\begin{array}{l}\text { Dialogic and } \\
\text { meaning mainly conveyed } \\
\text { through everyday oral } \\
\text { speech }\end{array}$ \\
\hline $\begin{array}{l}\text { Interpre- } \\
\text { tation }\end{array}$ & $\begin{array}{l}\text { The group assigns } \\
\text { one pupil to write } \\
\text { (i.e., who is in con- } \\
\text { trol). }\end{array}$ & $\begin{array}{l}\text { Nutrition and successful repro- } \\
\text { duction as factors in a two-factor } \\
\text { causal explanation (general and } \\
\text { specific conceptual knowledge) }\end{array}$ & Written text (no images) \\
\hline
\end{tabular}

\section{Deliberation on the epistemic affordances of the giraffe}

Although goal and purpose are not part of the example's epistemic affordance, they provide the context to enable an interpretation. As researchers, we should be careful in speculating about the cognitive and the affective goals and purposes of this example because the teacher did not specify any. However, the fairly open question and the brainstorm activity allude to affective engagement and to an introduction to a conceptual learning about evolution. The process of scientific knowledge is not addressed explicitly although it can be observed as an implicit part of the task given to the pupils. The analytical tool enables us to deliberate on alternatives to communication and knowledge.

Conceptual learning of evolution and natural selection comprises topics that are abstract and difficult to grasp. The dialogical approach enables different views on evolution. However, the purely verbal approach perhaps does not provide the pupils with much support in dealing with the variations and the unseen processes of evolution. Applying a broader range of the multimodal assembly in the communication, rather than relying heavily on speech and writing modes, might further support the pupils' learning. Perhaps, if the teacher had chosen several pictures carefully (e.g., a giraffe bending down and grazing), she could have challenged the pupils more than just by showing a picture of a giraffe stretching its neck. The pupils waver between a teleological explanation (i.e., the giraffes are actively adapting to the milieu by stretching their necks) and a view that some are born with longer necks (i.e., natural variation). The tension between these two explanations can be considered a Lamarckian view existing alongside one that is more aligned with contemporary evolutionary theory. The choice of an extreme trait such as the giraffe's long neck and the perception about the giraffe as a beautiful and graceful mammal provide the pupils with a potential for an important emotional engagement in the example. The affective aspects could also have been strengthened through the use of visual media. The pupils were assigned a great part of the responsibility for the learning process themselves; this might of course lead to interpretations that would not be aligned with established science.

Evolution and concepts, such as natural selection and variation, could provide opportunities for exploring different hypotheses and pieces of evidence in the classroom, in addition to being an interesting lesson about the history of science. By letting the pupils consider different possible explanations for the giraffe's long neck, the teacher opens up many ideas involving plausible connections between the long neck and several factors, such as reproduction, food and predators. This approach could lead to a discussion on simple versus complex explanations of evolution. To what extent does the "solution" of the giraffe's long neck apply to other species as well? Linking the development of one species to the principles of evolution is challenging. 


\section{Second example: Genes control traits}

The genes control traits example stems from an ethnographic-oriented case study (Johansen, 2013). However, that project's research focus was not the use of examples but scientific literacy in a broader sense. The transcript used here is mainly based on video footage focusing on the teacher at the board, in addition to field notes capturing the entire teacher-class interaction. The pupils are approximately 16 years old and usually pay attention but ask few questions and seldom display any enthusiasm for school science. The previous week, they had started on a new topic on biology, including cell biology, heritage and biotechnology.

\section{Genes control traits deconstructed}

The teacher introduces the topic of DNA and genes and somewhat includes the pupils by using closed questions (Excerpt 3).

Excerpt 3. Teacher's introduction about DNA and genes (this excerpt is slightly edited for readability)

Teacher How many DNA molecules do we have in each cell?

Pupil 43 (?)

Teacher In each cell, we have 46 DNA molecules. I do not think that one has understood completely the mechanism of the DNA molecule, but one has understood quite a lot. Does anyone know why we have got 23 pairs? Why have we got two and two similar genes?

Pupil One spare.

Teacher We got them in pairs. Why do we have genes in pairs? Yes, we have pairs. We have for example sex chromosomes - I use the word chromosomes - the DNA molecules are wrapped up, so they have the same structures as you know for chromosomes. (Draws a sketch of chromosomes on the board and points at the sketch). This we know as chromosomes; it is DNA that is wrapped around a protein skeleton. They come in pairs, these chromosomes.

Teacher (makes another drawing of chromosomes, draws a small circle on it and points) On this pair, the gene for eye colour, gene for hair colour, how we fold our hands, gene for if we do such (and such), gene for free or attached ear flips.

The teacher is in control during the orientation; she leads and seems to have a set direction for the communication (see Table 5 for the summary). She presents the knowledge through the concepts of DNA and chromosomes. These concepts are not elaborated here (she does so later); this is general conceptual knowledge. The teacher refers to professional science in her comment, "one has understood quite a lot"; the scientific knowledge process entails the quest to unravel the DNA mechanisms. The overall impression is that the teacher is delivering a monologue - she decides what the relevant questions are and the appropriate pace. She relies on verbal language; however, to underscore some of her points, she makes drawings on the board.

Table 5. Genes control traits: orientation

\begin{tabular}{|l|l|l|l|}
\hline Stage & Who & What knowledge & How \\
\hline $\begin{array}{l}\text { Orien- } \\
\text { tation }\end{array}$ & $\begin{array}{l}\text { Teacher talks and con- } \\
\text { trols conversation Pupils } \\
\text { answer questions and } \\
\text { are included to some } \\
\text { degree }\end{array}$ & $\begin{array}{l}\text { DNA, chromosomes and genes } \\
\text { (abstract conceptual knowledge) } \\
\text { Scientific processes are portrayed } \\
\text { as “understanding the mecha- } \\
\text { nism of DNA". }\end{array}$ & $\begin{array}{l}\text { Mostly monological } \\
\text { and verbal, supported } \\
\text { by drawing on the } \\
\text { board }\end{array}$ \\
\hline
\end{tabular}


The incident depicted in Excerpt 4 follows directly after Excerpt 3.

Excerpt 4. The rest of the example (slightly edited for readability)

Teacher If we can roll our tongues. Let us test that - how many can ...

Pupils (Start talking and sharing experiences)

Pupil Dogenes control everything?

Teacher It controls very much. It does. Is it not strange what is in control of tongue rolling? It is a signal from the DNA molecule that is produced in cells that makes you unable to [roll your tongue].

The teacher initiates incident by asking the closed question, "Let us test that - how many can [roll their tongues]?" This is an action that the pupils either can or cannot perform. The pupils' task in the incident involves testing their tongue-rolling ability and sharing experiences - laughing and talking. The teacher is in control and includes the pupils in the activity. After this activity, one pupil takes the initiative to ask a relevant question, "Do genes control everything?" The teacher explains and makes some sort of interpretation, "It is a signal from the DNA molecule that is produced in cells that makes you unable to (roll your tongue)". By doing so, the teacher reconfirms that she is in control concerning knowledge.

In the incident, the knowledge (rolling the tongue) is specific, felt and seen; it is closely related to the experiences of bodily action rather than a conceptual understanding. At the end of the example, the teacher sums it up - as an answer to a pupil's prompt. Her interpretation is the judgement that "It [genes] controls very much". This is a general statement - it is not coupled with tongue rolling. In the incident and the subsequent short interpretation, a dialogic approach to communication is employed. On the other hand, the interpretation is made orally by the teacher alone. Table 6 summarises these descriptions.

Table 6. Genes control traits: incident and interpretation.

\begin{tabular}{|l|l|l|l|}
\hline Stage & Who & What knowledge & How \\
\hline Incident & $\begin{array}{l}\text { The teacher provides } \\
\text { a closed question and } \\
\text { includes the pupils. }\end{array}$ & $\begin{array}{l}\text { Rolling tongues: } \\
\text { This is knowledge } \\
\text { that belongs to each } \\
\text { pupil; it is specific. }\end{array}$ & $\begin{array}{l}\text { The teacher gives an oral instruction, } \\
\text { and the pupils perform the activity } \\
\text { with their tongues (meaning that it } \\
\text { is felt). Some of them later verbalise } \\
\text { their experiences. }\end{array}$ \\
\hline $\begin{array}{l}\text { Inter- } \\
\text { preta- } \\
\text { tion }\end{array}$ & $\begin{array}{l}\text { A pupil asks a question, } \\
\text { and the teacher signifies } \\
\text { that she is in control by } \\
\text { providing the answer }\end{array}$ & $\begin{array}{l}\text { General conceptual } \\
\text { explanation related } \\
\text { to the activity }\end{array}$ & Dialogical and purely oral language \\
\hline
\end{tabular}

\section{Deliberation on epistemic affordances of genes control traits}

One should be careful in speculating about the cognitive and the affective goals and purposes of this example because the teacher did not specify any. However, the connections among abstract concepts, such as DNA, chromosomes and genes, are difficult for the pupils to understand. Concretising "the effects of genes" by observing their own traits might thus help the pupils understand what the topic 
is about. It is not just science terminology and a peculiar drawing on the board - it has the potential to create a link between genes and (observable) traits. The teacher probably draws on previous experiences with this example as engaging pupils; they seem to enjoy it. The bodily representation of knowledge - an approach to learning that is perhaps rare in science classrooms - is a strong affective factor. In other words, by using the pupils' tongues - this example creates the potential for the pupils to "experience" the relationship between traits and genes. However, this relationship needs to be supported. Here, the transition to the stages of incident and interpretation might be elusive for the pupils because the conceptual knowledge on genes and DNA is mainly communicated verbally. Since the concepts are highly abstract and on another organisational level than the experienced trait, it might be difficult for the pupils to connect these.

In this case, it is claimed that genes control "very much". However, there could be an opportunity to elaborate on scientific knowledge processes, with nuances of what is genetically controlled and what is an adaptation to the environment. Moreover, rolling the tongue is treated as evidence of a trait that is an effect of our genetic makeup. However, there is a loose connection - how can we be sure that this trait is a result of genes? In this case, the teacher makes the connection. In other words, what is considered "evidence" and "true" is so because the teacher says it is. For the pupils, there might be a loose coupling between "genes" and their own traits. Moreover, they might get the impression that one gene is responsible for a specific trait. It is a question of whether this example simplifies more complicated relationships among genes, the environment and traits. Perhaps, if the teacher uses carefully chosen examples of visual traits, including examples revealing epigenetics (the mechanism of turning genes on and off that is related to our environment), the pupils would broaden their understanding of (causal) relationships between genes and traits.

\section{DISCUSSION}

In this article, we have developed an analytical tool to deconstruct examples and deliberate on their potential for pupils' learning. Examples are regarded as constituting a specific form of social interaction in the classroom. The tool is developed by fusing genre theory with the concept of epistemic affordance.

When applied in teacher education, the tool involves three steps: first, to identify the goal and the purpose; second, to deconstruct who is involved and their relationships, what knowledge is at stake and how knowledge is communicated; and third, to deliberate on the example's epistemic affordance. Figure 1 shows our visual representation of the tool. Activities in the classroom, including examples, are driven by goals and purposes. This means that an example should be "understood" in the light of its goals and purposes. The tool enables a deconstruction of the example by identifying the three variables: the relationship between the teacher and the pupils (who), what knowledge is at stake and how it is communicated. We propose some questions for each of these variables to focus on the deconstruction of the example. We have identified the stages from the incident to the orientation and to the final interpretation of two examples by applying the tool. Being aware of the timeline from the start to the end of the example is important, especially the connection between the concrete core of the example and the more abstract or general orientation and interpretation. To enable a deliberation on the example's epistemic affordance for the pupils, the combination of "what knowledge" and "how" from the deconstruction is of interest (see also the Epistemic affordance section). 


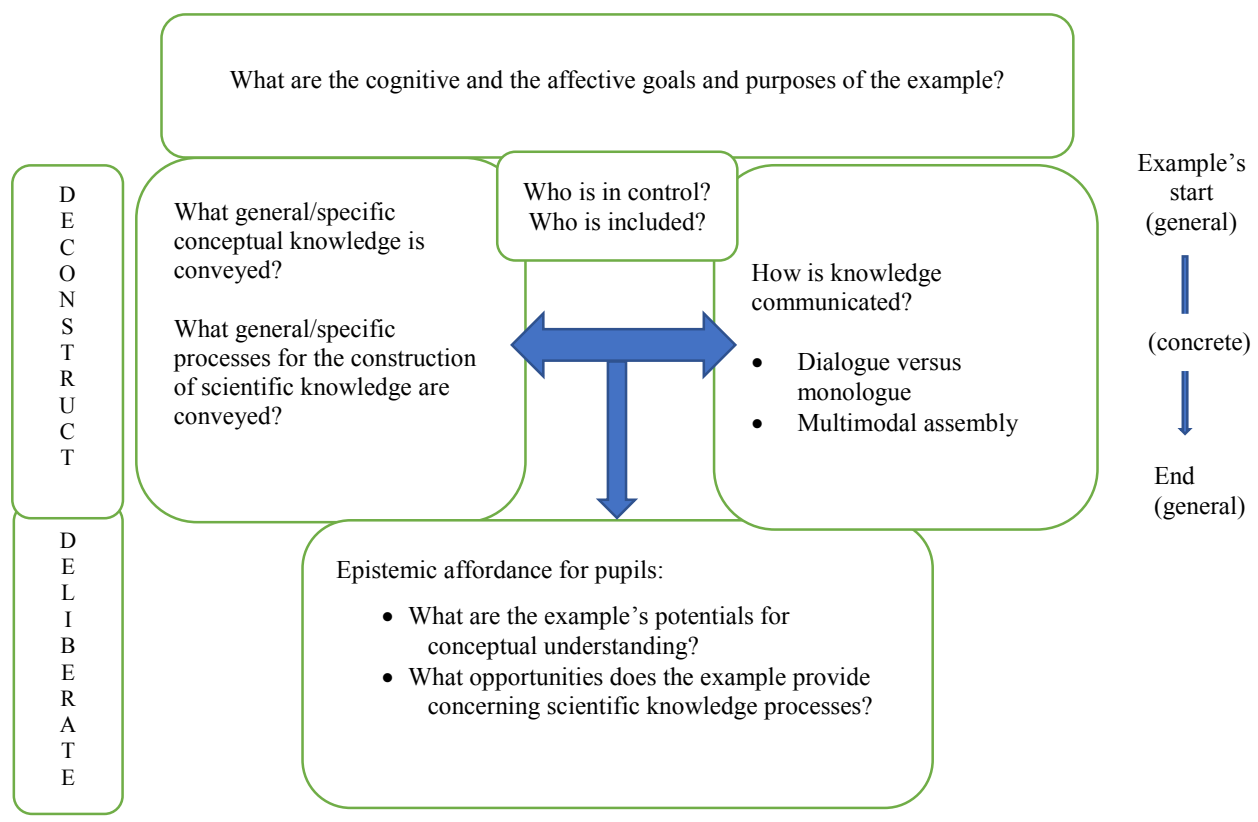

Figure 1. Visualisation of the analytical tool as a set of questions

The strength of this analytical tool lies in its applicability to investigating how the communicative process unfolds over time, as well as bringing empirical and theoretical depth to the classical didactic questions of what, how and who. However, the tool has weaknesses. The roles of ethical and aesthetic goals and purposes are downplayed, and the tool overlooks constraining factors, such as the curriculum, time and physical space.

We agree with Brown's (1992) argument that teachers need to carefully construct examples in order to promote their pupils' learning. Identifying the possibilities for learning - as well as the pitfalls - is thus an important aspect of constructing examples. As both the giraffe and the genes control traits examples show, the teacher needs a substantial amount of knowledge about both scientific content and scientific processes to deliberate on an example's epistemic affordance. The two examples are meant to illustrate abstract concepts - such as evolution, DNA and genes - and both teachers introduce these almost solely by using oral language. Even if the pupils have heard these terms before, their scientific meanings might not be equally clear. It is difficult to ascertain the link between the concrete core of the example (e.g., rolling the tongue) and the example's conceptual starting and ending points (genes and DNA). It becomes a question of whether the consequence is that the interpretation stage does not make sense for the pupils (cf. Brown, 1992). To remedy this problem, it is possible for teachers to carefully choose visual representations, among others, that can both support and challenge the pupils' ideas. Additionally, the teacher needs to choose appropriate science content and representations in order to stimulate the pupils' emotions, such as feelings of wonder and awe, as well as arouse their intellectual curiosity.

It is vital to be aware of how science content is presented through examples as it is easy to pass on the teachers' own experiences from their previous education (Loughran, 2014). To overcome recycling of examples that seemingly work, we argue that the exercise of deconstructing and deliberating on epistemic affordance is important. For instance, the use of video materials showing examples as part of classroom teaching can promote reflective practices among student teachers (Martin \& Siry, 2012). 
It is also essential to discuss the social relationships between the teacher and the pupils; what are they, and what should they be? Even if there are no obviously "right" answers to these questions, it is nevertheless crucial for student teachers to think about how they can include the pupils and how they exercise their control over science content when using examples. For instance, the student teachers need to consider when to choose monologue rather than a dialogue with the pupils. The monologue provides a greater possibility to exercise teacher's control on science content, while the dialogue at its best provide all the pupils with a possibility to voice different views and contribute to collective meaning-making. Lastly, the awareness of an example's goal and purpose is paramount. For student teachers, this could mean trying to identify both conceptual and affective goals of the example. As teachers, we want our pupils to learn something general from the particularity of the example. This aspiration implies that in science, student teachers should be cognisant of the extent to which the pupils can make inferences from the example, as well as at what point the teacher needs to provide additional information.

We do encourage science teacher educators and students to further explore the possibilities and the limitations of this analytical tool. Will tacit practices concerning examples be explicit when using a tool such as this? According to Collins (2001), there will always be tacit elements of how we understand the world that we live in, but hopefully, by constructive critical engagement - and using examples - more aspects of teaching practices will become explicit.

\section{REFERENCES}

Alsop, S., \& Watts, M. (2003). Science education and affect. International Journal of Science Education, 25(9), 1043-1047.

Berry, A., \& Loughran, J. (2012). Developing Science Teacher Educators' Pedagogy of Teacher Education. In B. J. Fraser, K. G. Tobin, \& C. J. McRobbie (Eds.), Second International Handbook of Science Education (Vol. 1, pp. 401-415). Dordrecht: Springer.

Bjønness, B., \& Knain, E. (2018). A science teacher's complex beliefs about nature of scientific inquiry. NorDiNa, 14(1), 54-67. doi:http://dx.doi.org/10.5617/nordina.2676

Brown, D. E. (1992). Using examples and analogies to remediate misconceptions in physics: Factors influencing conceptual change. Journal of Research in Science Teaching, 29(1), 17-34.

Chi, M. T. (2005). Commonsense conceptions of emergent processes: Why some misconceptions are robust. Journal of the Learning Sciences, 14(2), 161-199.

Cole, M., \& Engeström, Y. (1993). A Cultural-historical Approach to Distributed Cognition. In G. Salomon (Ed.), Distributed Cognitions. Psychological and Educational Considerations (pp. 1-46). Cambridge: Cambridge University Press.

Coll, R. (2015). Analogies in Science. In R. Gunstone (Ed.), Encyclopedia of Science Education. (pp. 41-42). Dordrecht: Springer.

Collins, H. M. (2001). What is Tacit Knowledge? In T. R. Schatzki, K. K. Cetina, \& E. Von Savigny (Eds.), The Practice Turn in Contemporary Theory (pp. 107-119). Oxon: Routledge.

Duschl, R. A., \& Wright, E. (1989). A case study of high school teachers' decision making models for planning and teaching science. Journal of Research in Science Teaching, 26(6), 467-501. doi:https://doi.org/10.1002/tea.3660260602

Emmons, N. A., \& Kelemen, D. A. (2015). Young children's acceptance of within-species variation: Implications for essentialism and teaching evolution. Journal of Experimental Child Psychology, 139, 148-160.

Fraser, B. J., Tobin, K., \& McRobbie, C. J. (Eds.). (2011). Second International Handbook of Science Education. Dordrecht: Springer.

Gibson, J. J. (1977). The Theory of Affordances. In R. Shaw \& J. Bransford (Eds.), Perceiving, Acting and Knowing. Toward an Ecological Psychology (pp. 67-82). Hillsdale: Lawrence Erlbaum. 
Goodyear, P., Carvalho, L., \& Dohn, N. B. (2014). Design for networked learning: framing relations between participants' activities and the physical setting. Paper presented at the Proceedings of the 9th International Conference on Networked Learning 2014. Edinburgh.

Gunstone, R. (Ed.). (2015). Encyclopedia of Science Education. Dordrecht: Springer.

Jaeger, A. J., \& Wiley, J. (2015). Reading an analogy can cause the illusion of comprehension. Discourse Processes, 52(5-6), 376-405.

Johansen, G. (2013). 'Science for all' - a mission impossible? A multimodal discourse analysis of practical work and inquiry in Norwegian upper secondary school. (Doctoral dissertation). Norwegian University of Life Sciences. Retrieved from http://brage.bibsys.no/xmlui/bitstream/ handle/11250/196934/1/Science\%2ofor\%20all-\%20with\%2op\%201.pdf

Lamarck, J.-B. (1914/1984). Zoological Philosophy: An Exposition with regard to the Natural History of Animals. Chicago: University of Chicago Press.

Lederman, N. G., \& Abell, S. K. (Eds.). (2014). Handbook of Research on Science Education. Oxon: Routledge.

Lederman, N. G., \& Lederman, J. S. (2014). Research on Teaching and Learning of Nature of Science. In N. G. Lederman \& S. K. Abell (Eds.), Handbook of Research on Science Education (Vol. II, pp. 600-620). New York: Routledge.

Loughran, J. J. (2014). Developing Understandings of Practice: Science Teacher Learning. In N. G. Lederman \& S. K. Abell (Eds.), Handbook of Research on Science Education. (Vol. II, pp. 811829). Oxon: Routledge.

Marcelos, M. F., \& Nagem, R. L. (2012). Use of the "tree" analogy in evolution teaching by biology teachers. Science \& Education, 21, 507-541. doi:10.1007/s11191-011-9370-3

Martin, J. R. (2009). Genre and language learning: A social semiotic perspective. Linguistics and Education, 20, 10-21.

Martin, J. R., \& Rose, D. (2008). Genre Relations: Mapping Culture. London: Equinox Publishing.

Martin, S. N., \& Siry, C. (2012). Using Video in Science Teacher Education: An Analysis of the Utilization of Video-based Media by Teacher Educators and Researchers. In B. J. Fraser, K. G. Tobin, \& C. J. McRobbie (Eds.), Second International Handbook of Science Education (Vol. 1, pp. 417-433). Dortrecht: Springer.

Matlock, P. (1952). Identical twins discordant in tongue-rolling. Journal of Heredity, 41(1).

Mavrikis, M., Noss, R., Hoyles, C., \& Geraniou, E. (2012). Sowing the seeds of algebraic generalization: Designing epistemic affordances for an intelligent microworld. Journal of Computerassisted Learning, 29(1). doi:10.1111/j.1365-2729.2011.00469.x

Rocksén, M. (2015). Reasoning in a Science Classroom. (Doctoral dissertation). Gothenburg Studies in Educational Sciences (Vol. 365). Retrieved from https://gupea.ub.gu.se/handle/2077/38324

Smith, M. U. (2010). Current status of research in teaching and learning evolution: II. Pedagogical issues. Science \& Education, 19(6-8), 539-571. doi:10.1007/s11191-009-9216-4

Treagust, D. (2015). Analogies: Uses in Teaching. In R. Gunstone (Ed.), Encyclopedia in Science Education. (pp. 49-51). Dordrecht: Springer.

Trommler, F., Gresch, H., \& Hammann, M. (2018). Students' reasons for preferring teleological explanations. International Journal of Science Education, 4O(2), 159-187.

Williams, E. M. (2016). Giraffe stature and neck elongation: Vigilance as an evolutionary mechanism. Biology, 5(3), 35. doi:10.339o/biology5030035 


\section{AppendiX}

Excerpt 1, full version in Swedish, time interval [(0:31:51.5)-(0:32:46.3)]

S1, S2, S3 mark three different students.

(0:31:51.5) S1: vad eh, vad ska vi skriva sen då?

(0:31:54.7) S2: mm, så att den kan nå löven eh, asså för att för att så många så att för att så många som möjligt ska överleva eh, de utvecklas till att få långa halsar de som har långa halsar får mer mat de blir starkare de övervinner fighter och de lever (0:32:08.3) och deras barn överlever så då blir alla såna, bra giraffer

(o:32:13.7) ((skratt))

S2: men vänta

S3: är inte giraffen typ utrotningshotad?

S2: nä det tror jag inte eller jag vet inte, jag har aldrig hört det men kolla här (0:32:16.6) S3: det tror jag (0:32:19.1)

S1: eftersom den bra maten finns där uppe då är det ju dom girafferna som är långa som har tillgång till den maten (o:32:26.2) och då blir de ännu starkare, och då blir de S1: ja

S2: och så föder de barn och då vinner de så här eller så om det blir liksom slagsmål så de ska springa ifrån ett lejon typ till exempel då vinner de det för de är så starka för de får så bra mat, sen när de föder en unge så blir den också bra

S1: det är lite så som att vi människor vi har ju växt för varje år det är ju bara för att vi fått mer mat å liksom e det inte så

S2: jag vet inte

(o:32:46.3) S3: men de hade ju typ ingen mat ((ohörbart)) 